\title{
MODEL PEMBELAJARAN PERPADUAN SISTEM DARING DAN PRAKTIKUM UNTUK MENINGKATKAN KEMAMPUAN KOGNITIF DAN PSIKOMOTOR
}

\author{
Nyoto Suseno $^{1}$, Riswanto ${ }^{1}$, Arif Rahman Aththibby ${ }^{1,2}$, Dedy Hidayatullah Al-Arifin ${ }^{1}$, \\ M. Barkah Salim ${ }^{1}$ \\ Pendidikan Fisika, FKIP, Universitas Muhammadiyah Metro ${ }^{1}$. \\ Program Pascasarjana, Universitas Negeri Yogyakarta ${ }^{2}$. \\ Email: nyotoseno@gmail.com
}

Diterima: 19 Oktober 2020. Direvisi: 15 Februari 2021. Disetujui: 15 Maret 2021.

\begin{abstract}
Abstrak
Pandemi covid 19 memaksa pembelajaran daring menjadi pilihan dalam pelaksanaan pembelajaran, dan kemungkinan akan menjadi kelaziman baru pada era Revolusi Industri 4.0 saat ini. Pembelajaran daring cukup potensial untuk meningkatkan kemampuan aspek kognitif, namun untuk mengembangkan aspek psikomotor rasanya cukup sulit jika menggunakan pembelajaran daring. Tujuan penelitian ini adalah pengambangan model pembelajaran daring yang dipadukan dengan praktikum untuk meningkatkan kemampuan kognitif dan psikomotor. Penelitian menggunakan pendekatan kuantitatif dan kualitataif. Pendekatan kuantitatif digunakan untuk mengolah data hasil belajar kognitif dan psikomotor sebagai efek penggunaan model yang dikembangkan, dan pendekatan kualitatif digunakan dalam mengungkap kelebihan dan kelemahan model yang dikembangkan. Hasil analisis data menunjukkan bahwa model pembelajaran perpaduan sistem daring dan praktikum berpengaruh signifikan dan efektif dalam meningkatkan kemampuan aspek kognitif (N-Gain=56,4\%), maupun aspek psikomotor $(\mathrm{N}$ Gain $=81,77 \%$ ). Berdasarkan hasil penelitian, maka model pembelajaran sistem daring dipadu dengan praktikum dapat dipergunakan dalam situasi wabah covid-19. Pelaksanaan praktikum hendaknya terjadwal dan dilaksanakan secara kelompok sesuai lokasi kedekatan tempat tinggal peserta didik.
\end{abstract}

Kata Kunci: pembelajaran daring, praktikum, kognitif dan psikomotor

\begin{abstract}
The Covid 19 forces the use of e-learning as an alternative in learning. Elearning is effective for the cognitive objectives, but it is difficult to develop psychomotor aspects. The purpose of this research is to develop an hybridlearning model combined online and practicum activities. This research uses a quantitative and qualitative approach The quantitative approach is used to process data on cognitive and psychomotor learning outcomes as an effect of using the developed model, while the qualitative approach is used to reveal its strengths and weaknesses. The results showed that the learning model has a significant and effective effect in improving cognitive aspects $(N$-Gain $=$ $56.4 \%)$ and psychomotor aspects $(N$-Gain $=81.77 \%)$. The research
\end{abstract}


Suseno et al. -Model Pembelajaran Perpaduan Sistem ...

implication is learning model can be used in the covid-19 pandemic situation.

Keywords: e-learning, practicum, cognitive and psychomotor.

\section{PENDAHULUAN}

Pembelajaran dalam jaringan (daring) di era revolusi industri 4.0 menjadi suatu kelaziman baru. Revolusi industri 4.0 memberikan konsekuensi perubahan dan penyesuaian di berbagai bidang, termasuk pendidikan (Suseno, Harjati, Partono, Riswanto \& Al Arifin, 2019). Adanya pandemi covid 19 juga mendorong penyelenggaraan pembelajaran tidak dilaksanakan secara tatap muka. Sehingga pembelajaran daring menjadi alternatif yang populer untuk menghindari penyebaran covid 19.

Capaian pembelajaran dalam taksonomi Bloom meliputi aspek: afektif, kognitif dan psikomotor (Anderson, et al., 2001). Sedangkan taksonomi Marzano \& Kendall (2008) hasil belajar meliputi 6 level yang dibagi dalam tiga sistem mental, yaitu level 1 sampai 4 sebagai sistem kognitif, level 5 sebagai sistem metakognitif, dan level 6 sebagai sistem diri. Kemudian menurut Gagne
(1985) hasil belajar meliputi: keterampilan intelektual, kemampuan kognitif, sikap, informasi verbal dan keterampilan motorik. Pada artikel ini capaian pembelajaran dikelompokkan sesuai taksonomi Bloom.

Pada pembelajaran fisika aspek psikomotor melakukan eksperimen sangat penting untuk mendukung hasil belajar ranah kognitif dan sikap. Menurut Jones et al. (2016) kegiatan praktikum dapat meningkatkan pengalaman. Menurut Dittrich, Drosd, Minkin \& Shapovalov (2016), eksperimen laboratorium dapat meningkatkan pengetahuan dan pengalaman. Gandhi, Livezey, Zaniewski, \& Frazer (2016) mengemukakan bahwa kegiatan laboratorium dapat meningkatkan dua aspek sekaligus, yaitu perkembangan eksperimennya dan perkembangan pada diri peserta didik.

Planinsic (2009) mengemukakan bahwa dalam kegiatan laboratorium siswa mengalami situasi teori melalui pendekatan eksperimen dalam menyelesaikan masalah, sehingga 
Suseno et al. -Model Pembelajaran Perpaduan Sistem ...

siswa lebih yakin dalam covid-19 namun tetap efektif untuk mengemukakan idenya sendiri. mengembangkan aspek kognitif dan Suseno dan Riswanto (2017) telah psikomotar. Sebagai salah satu mengembangkan sistem pengelolaan alternatif adalah menggunakan laboratorium secara online, sehingga animasi atau simulasi yang banyak pelaksanaan praktikum lebih efektif dan efisien, karena data inventaris alat dan bahan laboratorium mudah diakses. Kemampuan eksperimen berpengaruh terhadap kemampuan lain. Hasil penelitian Suseno dan Harjati (2016), menemukan hubungan yang signifikan antara kemampuan praktikum dan kemampuan berpikir kreatif. Peranan praktikum sangatlah penting, karena dengan praktikum, dapat dikembangkan kemampuan peserta didik (mind-on dan hands-on), maupun metode atau strategi pelaksanaan praktikum.

Metode eksperimen memberikan hasil pembelajaran yang lebih bermakna, namun adanya pandemi covid-19 ini pembelajaran tatap muka beresiko untuk dilakukan. Teknologi saat ini, memungkinkan pembelajaran dilakukan secara daring, namun kemampuan praktikum sulit untuk dicapai. Karena itu perlu suatu model pembelajaran yang dapat meminimalkan resiko penularan tersedia pada sumber online, seperti $\mathrm{PhET}$ simulation, animasi pada situs ruang guru dan banyak lagi sumber virtual lainnya. Menurut Suseno, Partono dan Riswanto (2019) era revolusi industri 4.0 saat ini menyediakan sistem komunikasi dan penyimpanan yang sangat praktis menggunakan sistem cyber. Berbagai jenis data dapat disimpan dan diakses secara online, yang memudahkan pengguna untuk mencari data dan berinterkasi. Beberapa penelitian telah mengembangkan sumber belajar virtual. Aththibby dan Salim (2015) mengembangkan media pembelajaran berbasis animasi flash. Sari, Suseno dan Riswanto (2019) mengembangkan modul fisika berbasis web. Namun demikian, laboratorium virtual ini hanya mendukung pengembangan aspek kognitif, sedangkan aspek psikomotor kurang dapat dikembangkan.

Apapun tujuan pembelajarannya, dalam proses pembelajaran tatap 
Suseno et al. -Model Pembelajaran Perpaduan Sistem ...

muka, banyak alternatif strategi yang dapat dilaksanakan. Berbeda dengan situasi pandemi covid-19 yang pembelajarannya secara daring. Karya ilmiah ini mengungkap bagaimana strategi pembelajaran daring yang capaian pembelajarannya meliputi aspek kognitif dan psikomotor. Hal ini perlu kreatifitas dan pengalaman. Hasil penelitian Suseno (2014), bahwa keterampilan berpikir kreatif saja tidak cukup untuk menghasilkan guru yang kreatif.

Banyak sumber belajar yang tersedia di lingkungan peserta didik, dan untuk memberdayakannya diperlukan kreativitas untuk dapat menghubungkan antara sumber belajar dengan suasana belajar siswa. Guna menghindari penularan covid19, sarana di sekitar peserta didik cukup potensial sebagai alternatif dalam mengembangkan aspek psikomotor. Hanya saja, untuk memberdayakannya diperlukan suatu perangkat yang dalam tulisan ini disebut sebagai saluran belajar (learning channel). Pada artikel ini, learning channel diartikan sebagai perangkat pembelajaran yang menghubungkan antara sumber belajar dengan suasana belajar siswa. Untuk itu dilakukan penelitian pengembangan model pembelajaran perpaduan sistem daring dan praktikum untuk mengembangkan kemampuan kognitif dan psikomotor.

METODE

Penelitian ini dilaksanakan pada pembelajaran fisika yang capaian pembelajarannya meliputi aspek kognitif dan psikomotor. Pada penelitian ini pembelajaran menggunakan sistem pembelajaran daring (SPADA), guna menghindari penularan covid-19. Pengembangan aspek psikomotor dalam pembelajaran awalnya melalui kegiatan praktikum dengan memanfaatkan benda dan peralatan yang ada di sekitar peserta didik sebagai sumber belajar dan dilengkapi dengan modul praktikum mandiri. Hasil praktikum mandiri, ternyata kurang maksimal (Suseno \& Riswanto, 2020).

Penelitian diawali dengan need asessment melalui angket untuk membuat desain model pembelajaran perpaduan sistem daring dan praktikum yang sesuai dengan kondisi 
Suseno et al. -Model Pembelajaran Perpaduan Sistem ...

dan kebutuhan peserta didik pada masa pandemi covid-19 ini.

Analisis data dilakukan dengan pendekatan kuantitatif dan kualitatif, untuk mengungkap pengembangan model pembelajaran perpaduan daring dan praktikum secara komprehensif. Data kuantitatif digunakan untuk melihat efek model terhadap hasil belajar kognitif dan psikomotor, sedangkan data kualitatif digunakan untuk memperoleh gambaran model pembelajaran yang digunakan, serta keunggulan dan kelemahannya.

Pengolahan data kuantitatif dilakukan terhadap pengaruh model pembelajaran terhadap skor capaian pembelajaran dengan menggunakan uji statistik dan gain ternormalisasi. Sedangkan analisis data kualitatif meliputi: pemeriksaan dan pemilihan data, pengelompokkan data, tabulasi data, pengkategorian dan triangulasi data. Analisis data dilakukan dengan cara menguraikan serta menghubungkan data dengan berpedoman pada fokus penelitian, dan melakukan interpretasi untuk mengambil kesimpulan.

HASIL DAN PEMBAHASAN

\section{Analisis Kebutuhan}

Tahun 2020 ini terjadi pandemi Covid-19 yang memaksa semua pembelajaran yang semula dilakukan dengan tatap muka berubah menjadi pembelajaran mode daring. Capaian pembelajaran fisika meliputi aspek kognitif dan psikomotor. Untuk aspek kognitif dapat menggunakan mode daring, namun untuk aspek psikomotor kegiatan praktikum secara nyata sangat penting untuk dilaksanakan, meskipun ada alternatif mengganti kegiatan praktikum nyata dengan praktikum virtual.

Guna memastikan kesesuaian pilihan tersebut, telah dilakukan survai yang diikuti 40 responden, meliputi: dosen, guru, mahasiswa dan orang tua. Hasil survei menunjukkan bahwa yang menghendaki praktikum secara nyata lebih banyak dari yang virtual. Lebih lanjut ternyata seluruh mahasiswa memilih praktikum secara nyata, dengan alasan konsep dapat dibuktikan dengan lebih mudah dan cepat, dan pengalaman yang didapatkan berbeda dengan virtual. (Suseno \& Riswanto, 2020).

Sesuai hasil survai, maka dirancang model praktikum secara nyata. Sedangkan untuk memperkecil 
Suseno et al. -Model Pembelajaran Perpaduan Sistem ...

resiko penularan covid-19, dipilih kegiatan praktikum mandiri dengan memanfaatkan sumber belajar di lingkungan sekitar berupa: alat, bahan atau benda apa saja di sekitar peserta didik yang dapat dimanfaatkan untuk belajar melalui praktikum. Modul praktikum memandu peserta didik dalam belajar, sehingga terjadi interaksi antara peserta didik dengan sumber belajar di lingkungan sekitar, sebagai suasana belajar.

Setelah pelaksanaan praktikum mandiri, dilakukan survai menggunakan angket. Instrumen survai dikaitkan antara praktikum mandiri menggunakan lingkungan sekitar, dan praktikum di laboratorium yang biasa meraka lakukan. Hasil survai menunjukkan bahwa sebagaian besar $(91,0 \%)$ lebih senang praktikum di laboratorium. Dari seluruh responden, sebanyak $63,6 \%$ menyatakan praktikum di laboratorium lebih mengesankan dan bermakna, dan 36,4\% menyatakan praktikum menggunakan alat dan bahan di lingkungan sekitar mengesankan dan bermakna. Namun demikian semua menyatakan bahwa mereka mengalami kesulitan ketika praktikum mandiri menggunakan alat dan bahan di lingkungan sekitar. (Suseno \& Riswanto, 2020).

Pendapat mereka terkait praktikum mandiri menggunakan peralatan di lingkungan sekitar antara lain: memperhatikan protokol kesehatan, berkelompok dengan memperhatikan zonasi agar saling belajar, dan perlu mempertimbangkan kondisi daerah, panduan harus lebih rinci dan lebih mudah. Sedangkan saran untuk praktikum di laboratorium adalah: menerapkan protokol kesehatan secara tegas dan ketat, berkelompok, kegiatan praktikum tidak dipadatkan, sehingga menjadi sangat berat dan kurang memberikan hasil yang signifikan.

\section{Rancangan Pembelajaran}

Pembelajarn mode daring, Tahap 1 dimulai dengan penyampaian materi baik dalam bentuk power point ataupun video, kegiatan diskusi, dan penugasan. Setelah dilakukan perkuliahan daring, pada Tahap 2, dilakukan assessment terkait kemampuan penguasaan konsep. Tahap 3, kegiatan praktikum mandiri dengan memanfaatkan alat dan bahan di lingkungan sekitar, yang dipandu 
Suseno et al. -Model Pembelajaran Perpaduan Sistem ...

dengan modul praktikum. Kegiatan praktikum direkam dan dilaporkan baik proses maupun hasilnya dalam bentuk laporan tertulis dan video yang diunggah pada spada.ummetro.ac.id. Berdasarkan dokumen laporan praktikum mandiri, ditemukan beberapa materi belum dikuasai dan juga terjadi kesalahan konsep serta kesalahan dalam melaksanakan kegiatan praktikum (Suseno \& Riswanto, 2020).

Berdasarkan hasil temuan tersebut, dilakukan Tahap 4, yaitu remedial melalui perkuliahan secara daring dengan mereview materi, diskusi dan penugasan melalui fasilitas spada.ummetro.ac.id. Tahap 5 dilakukan Praktikum di Laboratorium dengan mengambil topik penting dan dibawah bimbingan. Serta terakhir Tahap 6, dilakukan assessment baik aspek kognitif maupun psikomotor. Model Pembelajaran perpaduan sistem daring dan praktikum dituangkan pada Gambar 1.

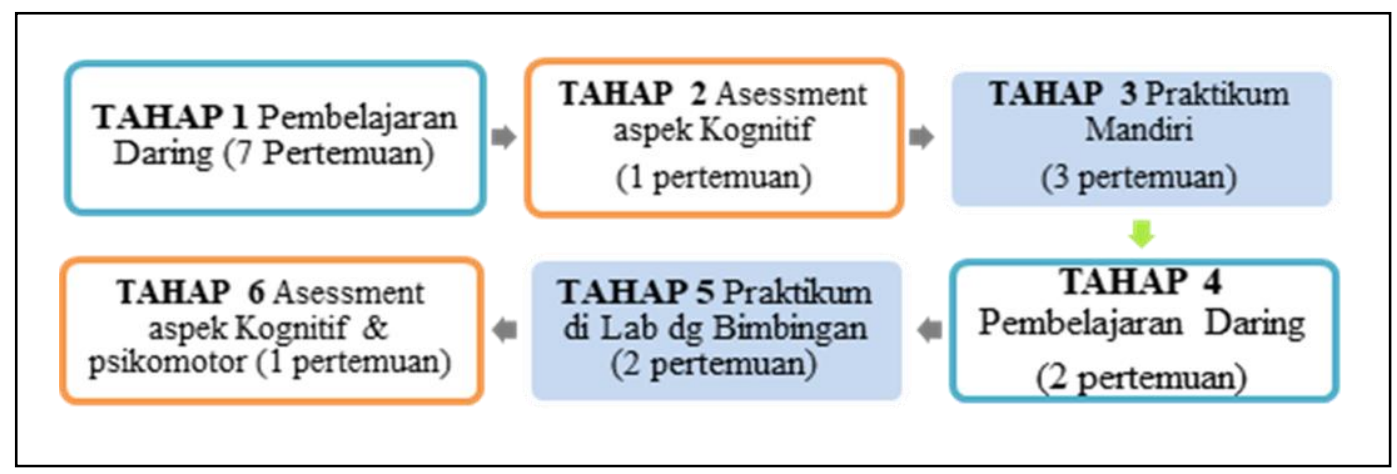

Gambar 1. Model Pembelajaran Perpaduan Sistem Daring dan Praktikum

\section{Data Hasil Pembelajaran}

\section{a. Hasil Belajar Ranah Kognitif}

Hasil belajar ranah kognitif dituangkan pada Tabel 1. Nilai ratarata hasil belajar aspek kognitif setelah kegiatan praktikum lebih besar dari sebelum praktikum. Selain itu juga tampak bahwa standar eror kemampuan kognitif sebelum praktikum lebih besar dari setelah kegiatan praktikum, yang berarti sebelum praktikum kemampuan mahasiswa variasinya cukup tinggi, dan setelah melakukan kegiatan 
Suseno et al. -Model Pembelajaran Perpaduan Sistem ...

praktikum, maka variasi kemampuan atau kesenjangan antar mahasiswa menjadi kecil.

Selain itu, hasil uji statistik yang dilakukan oleh Suseno \& Riswanto (2020) juga menunjukkan perbedaan yang signifikan, dimana hasil belajar setelah melakukan kegiatan praktikum lebih besar dari hasil belajar sebelum praktikum, dengan nilai gain ternormalisasi sebesar $56,4 \%$. Sesuai pengkategorian Hake (1999), dapat dikemukakan bahwa model perpaduan sistem daring dan praktikum cukup efektif dalam meningkatkan kemampuan aspek kognitif.

\section{b. Hasil Belajar Ranah Psikomotor}

Hasil belajar ranah psikomotor disajikan pada Tabel 2. Sesuai data tersebut, nilai rata-rata hasil belajar aspek psikomotor setelah kegiatan praktikum menggunakan lingkungan sekitar dan setelah praktikum di laboratorium, tampak sangat berbeda. Kemampuan praktikum di laboratorium lebih besar dari kemampuan praktikum mandiri menggunakan lingkungan sekitar. Selain itu juga tampak bahwa standar eror nilai kemampuan psikomotor ketika praktikum mandiri di lingkungan sekitar jauh lebih besar dari standar eror setelah kegiatan praktikum di laboratorium. Hal ini berarti bahwa kemampuan psikomotor dengan praktikum mandiri menggunakan peralatan di lingkungan sekitar variasinya cukup tinggi, dan setelah melakukan kegiatan praktikum di laboratorium, maka kesenjangan kemampuan psikomotor menjadi kecil.

Hasil uji statistik Tabel 3 memperlihatkan bahwa hasil belajar ranah psikomotor antara kegiatan praktikum mandiri menggunakan peralatan di lingkungan sekitar dan setelah praktikum di laboratorium berbeda secara signifikan, dengan nilai signifikansi 0,001 . Dengan demikian hasil belajar aspek psikomotor setelah praktikum di laboratorium lebih besar dari hasil belajar aspek psikomotor ketika praktikum mandiri menggunakan alat dan bahan di lingkungan sekitar.

Hasil perhitungan nilai gain ternormalisasi sebesar $81,77 \%$ dengan kategori sangat efektif. Dengan demikian kegiatan praktikum mandiri dengan menggunakan peralatan yang 
Suseno et al. -Model Pembelajaran Perpaduan Sistem ...

ada di lingkungan sekitar yang meningkatkan kemampuan aspek dilanjutkan dengan praktikum di psikomotor.

laboratorium sangat efektif dalam

Tabel 1 Deskripsi data Ranah Kognitif Sebelum dan Sesudah Kegiatan Praktikum

\begin{tabular}{llcccc}
\hline & & Mean & N & Std. Deviation & Std. Error Mean \\
\cline { 3 - 6 } Pair 1 & Kemampuan_Koqnitif_Sebelum_Praktikum & 80.4725 & 12 & 8.61716 & 2.48756 \\
& Kemampuan_Kognitif_Setelah_Praktikum & 91.5275 & 12 & 6.41382 & 1.85151 \\
\hline
\end{tabular}

Sumber: Suseno \& Riswanto, 2020.

Tabel 2. Deskripsi Data Ranah Psikomotor Saat Praktikum Menggunakan Peralatan di Lingkungan Sekitar dengan Praktikum di Laboratorium

\begin{tabular}{|c|c|c|c|c|c|}
\hline \multirow{3}{*}{ Pair 1} & & Mean & $\mathrm{N}$ & Std. Deviation & Std. Error Mean \\
\hline & $\begin{array}{l}\text { Kemampuan_Praktikum_Stlh_Pra } \\
\text { ktikum_di Lingkungan sekitar }\end{array}$ & 63.8333 & 12 & 15.97631 & 4.61196 \\
\hline & $\begin{array}{l}\text { Kemampuan_Praktikum_Setelah_ } \\
\text { Praktikum_di Laboratorium }\end{array}$ & 83.4442 & 12 & 2.18367 & 63037 \\
\hline
\end{tabular}

Tabel 3. Hasil Uji Beda Ranah Psikomotor

\begin{tabular}{|c|c|c|c|c|c|c|c|}
\hline \multicolumn{5}{|c|}{ Paired Differences } & \multirow[b]{4}{*}{$\mathrm{T}$} & \multirow[b]{4}{*}{ Df } & \\
\hline \multirow[b]{3}{*}{ Mean } & & & $95 \% \mathrm{C}$ & fidence & & & \multirow{3}{*}{$\begin{array}{l}\text { Sig. (2- } \\
\text { tailed) }\end{array}$} \\
\hline & Std. & $\begin{array}{l}\text { Std. } \\
\text { Error }\end{array}$ & $\begin{array}{r}\text { Intery } \\
\text { Dif }\end{array}$ & $\begin{array}{l}\text { of the } \\
\text { ence }\end{array}$ & & & \\
\hline & Deviation & Mean & Lower & Upper & & & \\
\hline
\end{tabular}

Kemampuan_Praktiku m_Stlh_Praktikum_di

lingkungan -

$\begin{array}{lllllll}-19.61 & 15.08 & 4.35 & -29.19 & -10.03 & -4.51 & 11\end{array}$

.001

Kemampuan_Praktiku m_Setelah_Praktikum _diLaboratorium

\section{Kelebihan dan Kelemahan}

Kelebihan dari model pembelajaran perpaduan sistem daring dan praktikum, adalah:

- kegiatan praktikum secara nyata lebih diminati dari pada virtual;
- praktikum di laboratorium lebih menyenangkan dari praktikum mandiri menggunakan peralatan di lingkungan sekitar, karena dalam praktikum mandiri semua mahasiswa merasa kesulitan. 
Suseno et al. -Model Pembelajaran Perpaduan Sistem ...

- pelaksanaan praktikum mandiri menggunakan peralatan di lingkungan sekitar, mengungkap kekurangan dan kesalahan konsep peserta didik lebih awal, sehingga dapat dilakukan remedial pada saat praktikum di laboratorium;

- pengalaman praktikum mandiri di lingkungan dilanjutkan dengan praktikum di laboratorium sangat bermakna dan efektif dalam meningkatkan kemampuan aspek kognitif dan psikomotor.

Kelemahan model pembelajaran perpaduan sistem daring dan praktikum, antara lain:

- praktikum menggunakan alat di lingkungan sekitar dilaksanakan secara mandiri (tidak berkelompok), sehingga ketika menemui kesulitan, peserta didik tidak segera mendapatkan bantuan belajar;

- praktikum mandiri di lingkungan sekitar kesulitan dalam menemukan alat ukur yang sesuai kebutuhan praktikum;

- pemadatan kegiatan praktikum di laboratorium pada akhir perkuliahan memberatkan dan kurang efektif.

\section{KESIMPULAN DAN SARAN}

\section{Kesimpulan}

1. Model pembelajaran perpaduan sistem daring dan praktikum meliputi 6 tahap, sebagaimana Gambar 1 terbukti mampu memberikan pengaruh secara signifikan dan efektif dalam meningkatkan kemampuan aspek kognitif $(\mathrm{N}-$ Gain $=56,4 \%)$ dan psikomotor $(\mathrm{N}-$ Gain $=81,77 \%)$.

2. Kelebihan model pembelajaran perpaduan sistem daring dan praktikum, antara lain:

- Kegiatan praktikum secara nyata (praktikum mandiri di lingkungan sekitar dan di laboratorium) lebih diminati, bermakna dan efektif dalam meningkatkan kemampuan kognitif dan psikomotor;

- Praktikum mandiri dapat mengungkap kesulitan peserta didik dan praktikum di laboratorium sebagai penguatan dalam meningkatkan aspek kognitif dan psikomotor. 
Suseno et al. -Model Pembelajaran Perpaduan Sistem ...

3. Kelemahan model pembelajaran perpaduan sistem daring dan praktikum, antara lain:

- Pelaksanaan praktikum dengan menggunakan peralatan yang ada di sekitar dilaksanakan secara mandiri, sehingga peserta didik tidak segera mendapatkan bantuan belajar ketika mendapat kesulitan;

- Kegiatan praktikum di laboratorium dilaksanakan dengan sistem pemadatan waktu dan materi, sehingga cukup memberatkan bagi peserta didik.

\section{Saran}

Sebagai implikasi dari temuan penelitian ini, maka dikemukakan saran sebagai berikut:

1. Untuk perkuliahan yang capaian pembelajarnya meliputi aspek kognitif dan psikomotor, maka model pembelajaran perpaduan sistem daring dan praktikum cukup efektif untuk digunakan sebagai alternatif pada masa pandemi covid 19 ini, dengan beberapa perbaikan dalam pelaksanaan praktikumnya.

2.Praktikum yang pelaksanaannya memanfaatkan lingkungan sekitar perlu didampingi dengan perangkat learning chanel berupa modul praktikum;

3. Praktikum yang memanfaatkan lingkungan sekitar, sebaiknya dalam pelaksanaannya secara kelompok dengan memperhatikan kedekatan tempat tinggal peserta didik, agar terjadi kolaborasi saling belajar dan membantu dalam menghadapi masalah belajar;

4. Pelaksanaan praktikum di laboratorium hendaknya diatur sedemikain rupa, sehingga tidak terlalu padat baik materi maupun waktunya sehingga peserta didik dapat mengikuti pembelajaran dengan lebih baik dan nyaman.

\section{UCAPAN TERIMA KASIH}

Ucapan terimakasih disampaikan kepada pimpinan UM Metro yang telah memberikan dukungan pembiayaan dalam penelitian ini melalui Surat Perjanjian Pelaksanaan Penelitian UM Metro Tahun Akademik 2019/2020 Nomor: 032/II.AU/C/LPPM/2020. 
Suseno et al. -Model Pembelajaran Perpaduan Sistem ...

\section{DAFTAR PUSTAKA}

Anderson, L. W. et al. (2001). A Taxonomy for Learning, Teaching, and Assessing: A Revision of Bloom's Taxonomy of Educational Objectives. New York: Addison Wesley Longman.

Aththibby, A. R. \& Salim, M. B. (2015). Pengembangan Media Pembelajaran Fisika Berbasis Animasi Flash Topik Bahasan Usaha dan Energi. Jurnal Pendidikan Fisika (JPF). 3(2), 2532.

http://dx.doi.org/10.24127/jpf.v3i2 .238

Dittrich, W., Drosd, R., Minkin, L., and Shapovalov, A. S. (2016). The Law of Entropy Increase - A Lab Experiment. The Physics Teacher. 54(6), 348-350. https://doi.org/10.1119/1.4961176

Gagne, R. M. (1985). The Cognitive Psychology of School Learning. Boston: Brown and Company.

Gandhi, P. R., Livezey, J. A., Zaniewski, A. M. and Frazer, D. R. D. (2016). Attending to Experimental Physics Practices and Lifelong Learning Skills in an introductory Laboratory Course. American Journal of Physics. 84(9), 696-703. https://doi.org/10.1119/1.4955147

Hake, R. 1999. Analyzing Change Gain Score. Indiana: Indiana University.

Jones, J.A., D’Addorio, A.J., Rojec, B.L., Milione, G. and Galvez, E.J. (2016). The Poincare-sphere Approach to Polarization: Formalism and New Labs with Poincare beams. American Journal of Physics. 84 (11), 822-835. https://doi.org/10.1119/1.4960468
Marzano, R. J. \& Kendall, J. S. (2008). Designing and Assessing Educational Objectives. Applying the New Taxonomy. California: Corwin Press.

Planinsic, Gorazd. (2009). IYPT Problem as an Efficient Source of Ideas for First-Year Project Laboratory Tasks. Eropean Journal of Physiscs. 30(6), 133 137. https://doi.org/10.1088/01430807/30/6/S04

Suseno, N. \& Riswanto. (2020). Hasil Belajar Model Pembelajaran Daring Disertai Praktikum Mandiri dengan Memanfaatkan Sarana di Lingkungan Sekitar. Seminar Nasional Penelitian dan Pengabdian kepada Masyarakat. 2020. Di Universitas Muhammadiyah Metro. Halaman: $89-98$.

Sari, F. A., Suseno, N., \& Riswanto. (2019). Pengembangan Modul Fisika Online Berbasis Web pada Materi Usaha dan Energi. Jurnal Inovasi Pembelajaran Fisika dan Riset Ilmiah (JIPFRI). 3(2), 129135.

https://doi.org/10.30599/jipfri.v3i2 .476

Suseno, N., Partono, \& Riswanto. 2019. Sistem Pengelolaan Laboratorium Sekolah Era Revolusi Industri 4.0. Depok: PT RajaGrafindo Persada.

Suseno, N., Harjati, P., Partono, Riswanto \& AlArifin, D.H. (2019). School Laboratory Management Information System. Journal of Physics: Conference Series. 1361 (1), 012068. https://doi:10.1088/1742$\underline{6596 / 1361 / 1 / 012068}$

Suseno, N. (2014). Pemetaan Analogi pada Konsep Abstrak Fisika. 
Suseno et al. -Model Pembelajaran Perpaduan Sistem ...

Jurnal Pendidikan Fisika. 2 (2), 110.

http://dx.doi.org/10.24127/jpf.v2i2 .118

Suseno, N. \& Harjati, P. (2016).

Experiment Role to Develop Metocognition Ability of

Prospective Teachers. The first International Conference on Low, Economics ang Education
(ICONLEE) 2016 di Bandar Lampung pada tanggal 12-13 Nopember 2016

Suseno, N. \& Riswanto. (2017). Sistem Pengelolaan Laboratorium Fisika untuk Mewujudkan Praktikum yang efisien. Jurnal Pendidikan Fisika. (5)1, 76-86. https://doi.org/10.30653/002.2017 $\underline{22.28}$ 